\title{
Nitrate limitation and ocean acidification interact with UV-B to reduce photosynthetic performance in the diatom Phaeodactylum tricornutum
}

\author{
W. Li ${ }^{1,2}$, K. Gao ${ }^{1}$, and J. Beardall ${ }^{3}$ \\ ${ }^{1}$ State Key Laboratory of Marine Environmental Science, Xiamen University (Xiang'an campus), \\ Xiamen, Fujian, 361102, China \\ ${ }^{2}$ College of Life and Environmental Sciences, Huangshan University, Huangshan, Anhui, 245041, China \\ ${ }^{3}$ School of Biological Sciences, Monash University, Clayton, VIC 3800, Australia
}

Correspondence to: K. Gao (ksgao@xmu.edu.cn)

Received: 8 November 2014 - Published in Biogeosciences Discuss.: 18 December 2014

Revised: 27 March 2015 - Accepted: 1 April 2015 - Published: 23 April 2015

\begin{abstract}
It has been proposed that ocean acidification (OA) will interact with other environmental factors to influence the overall impact of global change on biological systems. Accordingly we investigated the influence of nitrogen limitation and OA on the physiology of diatoms by growing the diatom Phaeodactylum tricornutum Bohlin under elevated

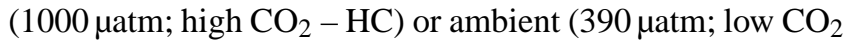
- LC) levels of $\mathrm{CO}_{2}$ with replete $\left(110 \mu \mathrm{mol} \mathrm{L}^{-1}\right.$; high nitrate $-\mathrm{HN})$ or reduced $\left(10 \mu \mathrm{mol} \mathrm{L}^{-1}\right.$; low nitrate $\left.-\mathrm{LN}\right)$ levels of $\mathrm{NO}_{3}^{-}$and subjecting the cells to solar radiation with or without UV irradiance to determine their susceptibility to UV radiation (UVR, $280-400 \mathrm{~nm}$ ). Our results indicate that OA and UVB induced significantly higher inhibition of both the photosynthetic rate and quantum yield under LN than under HN conditions. UVA or/and UVB increased the cells' non-photochemical quenching (NPQ) regardless of the $\mathrm{CO}_{2}$ levels. Under LN and OA conditions, activity of superoxide dismutase and catalase activities were enhanced, along with the highest sensitivity to UVB and the lowest ratio of repair to damage of PSII. HC-grown cells showed a faster recovery rate of yield under HN but not under LN conditions. We conclude therefore that nutrient limitation makes cells more prone to the deleterious effects of UV radiation and that $\mathrm{HC}$ conditions (ocean acidification) exacerbate this effect. The finding that nitrate limitation and ocean acidification interact with UV-B to reduce photosynthetic performance of the diatom $P$. tricornutum implies that ocean primary production
\end{abstract}

and the marine biological $\mathrm{C}$ pump will be affected by $\mathrm{OA}$ under multiple stressors.

\section{Introduction}

Increasing atmospheric levels of $\mathrm{CO}_{2}$ and the associated dissolution of $\mathrm{CO}_{2}$ into the oceans has resulted in ocean acidification (OA), with increased levels of $p \mathrm{CO}_{2}, \mathrm{HCO}_{3}^{-}$and $\mathrm{H}^{+}$and decreased $\mathrm{CO}_{3}^{2-}$ concentration. The acidity of surface oceans has increased by $30 \%$ (lowering $\mathrm{pH}$ by 0.1 ) since the Industrial Revolution and is expected to increase by $100-150 \%(0.3-0.4 \mathrm{pH})$ by the year 2100 (Orr et al., 2005). At the same time, increased sea surface temperatures are predicted to cause a shoaling of the surface mixed layer, which in turn will lead to enhanced exposure to sunlight (both as photosynthetically active radiation (PAR) and as UV radiation (UVR)). This enhanced stratification will also decrease upward transport of nutrients from deeper, nutrientrich layers, leading to more frequent/marked nutrient limitation (Cermeño et al., 2008). Global change is thus likely to cause changes in a multiplicity of factors that influence phytoplankton growth and it is thus critical to examine OA in the context of interactive effects with these other environmental drivers (Boyd, 2011).

Increased availability of $\mathrm{CO}_{2}$ in seawater appears in some cases to bring a low level of benefit to growth and photosynthesis of natural phytoplankton populations (Riebesell and 
Tortell, 2011, and references therein), though in most cases laboratory experiments have shown little effect of OA alone (Doney et al., 2009). However, the effects can differ according to changes in solar radiation and/or other physical or chemical factors (Gao et al., 2012a). Increased acidity of seawater may lead to physiological stress (Pörtner and Farrell, 2008) and affect phytoplankton nutrient uptake (Beman et al., 2011; Shi et al., 2012). Therefore, OA could most likely result in differential effects on different photosynthetic organisms or under different environmental conditions (Gao, 2011).

Diatoms account for about $20 \%$ of total global primary production and about $40 \%$ of that in the oceans (Granum et al., 2005). Early reports suggested that growth of diatom species could be limited by the availability of $\mathrm{CO}_{2}$ (Riebesell et al., 1993). However, the growth rate of diatom-dominated natural phytoplankton populations was not affected by $\mathrm{CO}_{2}$ enrichment to $800 \mu \mathrm{atm}$ (Tortell, 2000), and not all diatom species were sensitive to seawater $p \mathrm{CO}_{2}$ rise under nutrientreplete conditions in a mesocosm study (Kim et al., 2006). In laboratory experiments, growth of Skeletonema costatum was not stimulated by elevated $\mathrm{CO}_{2}(800 \mu \mathrm{atm}$; Chen and Gao, 2011). Phaeodactylum tricornutum grown under nitrate-limited conditions also showed no enhancement of growth under high $\mathrm{CO}_{2}(1000 \mu a t m$; Li et al., 2012a). Nevertheless, in other work, the diatoms Phaeodactylum tricornutum (1000 $\mu \mathrm{atm}$; Wu et al., 2010) and Attheya sp. (670 $\mu \mathrm{atm}$; King et al., 2011) showed enhanced growth rate in nutrientreplete conditions under elevated $\mathrm{CO}_{2}$ levels. These variable findings reflect physiologically differential responses among different species or under different experimental or environmental conditions. Changes in light intensity can lead to enhanced, unaffected or inhibited growth rates under OA conditions, even for the same diatom species (Gao et al., 2012b). Recently, microcosm studies have shown that the species abundance and physiological responses (e.g., Chl $a$, DNA damage, reactive oxygen species (ROS), photosynthetic efficiency) could be regulated by nutrients and light availability under high $\mathrm{CO}_{2}$ conditions (Neale et al., 2014; Sobrino et al., 2014). Therefore, the effects of OA should be considered in the context of the influence of multiple factors, such as temperature, nutrient status, light and UVR (Boyd, 2011; IPCC, 2011; Gao et al., 2012a).

Solar UVB radiation $(280-315 \mathrm{~nm})$, which is increasing due to interactions of global change and ozone depletion (Häder et al., 2011), is known to damage DNA (Buma et al., 2003; Gao et al., 2008), lower photosynthetic rates (Helbling et al., 2003), perturb the uptake of nutrients (Hessen et al., 2008) and alter morphological development (Wu et al., 2005) of phytoplankton. In contrast, under moderate levels of solar radiation, solar UVA radiation $(315-400 \mathrm{~nm})$ is known to stimulate photosynthesis (Gao et al., 2007), signaling (Cashmore, 1998) and photo-repair of UVB-induced damage (Buma et al., 2003) in phytoplankton. Previously, it was shown that UV-induced inhibition of dinoflagellates was lower under nutrient-replete conditions but higher under nutrient limitation due to less efficient repair resulting from lowered nutrient availability (Litchman et al., 2002). Similar enhancement of UVB impacts under nutrient (N, P) limitation were shown for a green microalga, Dunaliella tertiolecta (Shelly et al., 2002; Heraud et al., 2005). Recently, OA was found to enhance UVB-induced damage to a red tide alga, Phaeocystis globosa, leading to a greater decrease in growth rate and photochemical yield under $1000 \mu$ atm $\mathrm{CO}_{2}$ (Chen and Gao, 2011).

Marine phytoplankton often experience nutrient limitation in offshore waters; with progressive ocean warming, such limitation will be intensified due to the decreased depth of the surface mixed layer (enhanced stratification) (Cermeño et al., 2008). Combined effects of nutrient levels and $\mathrm{CO}_{2}$ have been reported in many studies. For example, photosynthetic carbon fixation of the coccolithophorid Emiliania huxleyi was enhanced under high light and low nitrogen conditions when the seawater $\mathrm{CO}_{2}$ concentration was raised to $2000 \mu \mathrm{atm}$ (Leonardos and Geider, 2005). However, increased seawater $\mathrm{CO}_{2}$ concentration also showed antagonistic effects with iron in modulating (down- or up-regulating) primary production of marine phytoplankton in the Gulf of Alaska (a nutrient-replete but low-chlorophyll area) (Hopkinson et al., 2010). In some toxin producing species, for example the dinoflagellate Karlodinium veneficum, toxicity was enhanced under high $\mathrm{CO}_{2}$ and low phosphate conditions (Fu et al., 2010). However, to the best of our knowledge, there is little information concerning the combined effects of $\mathrm{OA}$ and $\mathrm{NO}_{3}^{-}$limitation on diatoms and their susceptibility to damage from solar UVR (280-400 nm).

Nutrient availability can influence phytoplankton responses to UV and to $\mathrm{CO}_{2}$-induced seawater acidification. Theoretically, increased seawater acidity can perturb the intracellular acid-base balance and thus lead to differential interactions between nutrients and solar UVR. In this study, we hypothesize that reduced availability of $\mathrm{NO}_{3}^{-}$under $\mathrm{OA}$ would affect the photosynthetic performance under solar radiation with or without UVR. We used the diatom Phaeodactylum tricornutum to test this hypothesis.

\section{Materials and methods}

\subsection{Growth conditions}

The diatom Phaeodactylum tricornutum Bohlin (strain CCMA 106), isolated from the South China Sea (SCS) and maintained in the Center for Collections of Marine Bacteria and Phytoplankton (CCMBP) of the State Key Laboratory of Marine Environmental Sciences (Xiamen University), was grown mono-specifically in artificial seawater enriched with Aquil medium (Morel et al., 1979). Cells were cultured in $500 \mathrm{~mL}$ vessels containing $250 \mathrm{~mL}$ of medium under two levels of $\mathrm{NO}_{3}^{-}\left(110 \mu \mathrm{mol} \mathrm{L}^{-1}\right.$, high nitrate $-\mathrm{HN}$ 
and $10 \mu \mathrm{mol} \mathrm{L}{ }^{-1}$, low nitrate $-\mathrm{LN}$ ) and aerated with ambient (outdoor) air (low $\mathrm{CO}_{2}-\mathrm{LC} ; 390 \mu \mathrm{atm}$ ) or elevated

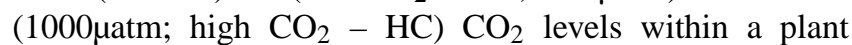
$\mathrm{CO}_{2}$ chamber (HP1000G-D, Ruihua Instrument and Equipment Co. Ltd, China). Gas flow rate was $300 \mathrm{~mL} \mathrm{~min}^{-1}$, and the $\mathrm{CO}_{2}$ concentrations varied by less than $3 \%$ of the target value. The low $\mathrm{NO}_{3}^{-}$level of $10 \mu \mathrm{mol} \mathrm{L}^{-1}$ was based on its concentration range (ca. $0-20 \mu \mathrm{mol} \mathrm{L}^{-1}$ ) in the oligotrophic SCS, from where the diatom strain was isolated. Dilutions were made every $24 \mathrm{~h}$, so that the seawater carbonate system was kept stable under each $\mathrm{CO}_{2}$ level within the cell density range of $6 \times 10^{4}$ to $3 \times 10^{5}$ cells mL ${ }^{-1}$ (exponential growth phase). According to the pre-experiment, the initial nitrate concentration of $10 \mu \mathrm{mol} \mathrm{L}^{-1}$ could be totally consumed $\left(0-10 \mu \mathrm{mol} \mathrm{L}^{-1}\right)$; and the initial nitrate concentration of $110 \mu \mathrm{mol} \mathrm{L}^{-1}$ treatment ranged from ca. 85$110 \mu \mathrm{mol} \mathrm{L}^{-1}$ during the culture. The cells were grown at $70 \mu \mathrm{mol}$ photons $\mathrm{m}^{-2} \mathrm{~s}^{-1}$ (cool white fluorescent tubes) under a $12 \mathrm{~L}: 12 \mathrm{D}$ photoperiod for at least 10 generations before being used for the solar radiation treatments described below. Three independent cultures were grown at each set of conditions.

\subsection{Determination of seawater carbonate system parameters}

The $\mathrm{pH}$ in the cultures was determined daily during the light period with a $\mathrm{pH}$ potentiometric titrator (DL15, MettlerToledo, Schwerzenbach, Switzerland), which was calibrated with NBS (National Bureau of Standards) buffer solutions (Hanna). DIC (dissolved inorganic carbon) was estimated with an automatic system (AS-C3, Apollo Scitech) linked to an infrared gas detector (Li-Cor 7000, Li-Cor). DIC, $\mathrm{pH}$, nutrient concentrations (phosphate, $10 \mu \mathrm{mol} \mathrm{L}^{-1}$; silicate, $\left.100 \mu \mathrm{mol} \mathrm{L}{ }^{-1}\right)$, salinity $(35)$ and temperature $\left(20^{\circ} \mathrm{C}\right)$ were used to calculate the parameters of the seawater carbonate system $\left(\mathrm{HCO}_{3}^{-}, \mathrm{CO}_{3}^{2-}, \mathrm{CO}_{2}\right.$ and TA) using the $\mathrm{CO}_{2}$ system analyzing software $\mathrm{CO}_{2} \mathrm{SYS}$ (Lewis and Wallace, 1998) as described previously (Li et al., 2012a). The carbonic acid dissociation constants $\left(K_{1}\right.$ and $\left.K_{2}\right)$ used were those of Roy et al. (1993), and that for boric acid $\left(K_{\mathrm{B}}\right)$ was from Dickson (1990).

\subsection{Radiation treatments under the solar simulator}

To determine the effects of growth conditions on the sensitivity of carbon fixation and chlorophyll fluorescence to short-term exposure to UVR, $P$. tricornutum cells, grown under LC-LN, HC-LN, LC-HN and HC-HN conditions, were exposed for $1 \mathrm{~h}$ to different radiation treatments with or without UVR, as follows: (1) PAR treatment, tubes wrapped with Ultraphan film 395 (UV Opak, Digefra), exposed to PAR alone; (2) PA treatment, tubes wrapped with Folex 320 (Montagefolie, Folex, Dreieich, Germany), receiving wavelengths above $320 \mathrm{~nm}$ (PAR + UVA); (3) PAB treat- ment, tubes wrapped with Ultraphan Film 295 (Digefra, Munich, Germany) so that the cells received wavelengths above $295 \mathrm{~nm}$ (PAR + UVA + UVB). The transmission spectra of the cut-off filters are available elsewhere (Zheng and Gao, 2009). Samples were placed at a distance of $1.2 \mathrm{~m}$ from a solar simulator (Sol 1200W, Dr. Hönle, Martinsried, Germany), so that the actual PAR light intensity to which the cells were exposed within the tubes (calculated taking into account the transmission properties of the quartz tubes and the filters) was $44.11 \mathrm{Wm}^{-2}$ (ca. $190.11 \mu$ mol photons $\mathrm{m}^{-2} \mathrm{~s}^{-1}$ ) which is close to the daytime mean photon flux in the middle of the photic zone (22-36 m depth in South China Sea, SEATS station). The corresponding UVA and UVB irradiances were $14.19 \mathrm{Wm}^{-2}$ (ca. $41.99 \mu \mathrm{mol}$ photons $\mathrm{m}^{-2} \mathrm{~s}^{-1}$ ) and $0.75 \mathrm{Wm}^{-2}$ (ca. $1.89 \mu \mathrm{mol}$ photons $\mathrm{m}^{-2} \mathrm{~s}^{-1}$ ). Irradiances were measured with a broadband filter radiometer (ELDONET, Real Time Computer, Möhrendorf, Germany). After the radiation treatments, the cells were replaced under their growth light level $\left(70 \mu \mathrm{mol}\right.$ photons $\left.\mathrm{m}^{-2} \mathrm{~s}^{-1}\right)$ to examine the recovery of photosynthetic performance. During the incubations, the tubes were maintained in a water bath at $20^{\circ} \mathrm{C}$ using a circulating cooler (Eyela, CAP-3000, Tokyo Rikakikai Co. Ltd., Tokyo, Japan).

\subsection{Measurement of carbon fixation}

The ${ }^{14} \mathrm{C}$ method was applied to measurements of marine photosynthetic carbon fixation (Nielsen, 1952), and has been detailed with modified protocols in many publications (HolmHansen and Helbling, 1995; Gao et al., 2007). Cells were harvested in the middle of the light phase, diluted with freshly made medium equilibrated with the designated concentrations of $\mathrm{CO}_{2}$ to a cell concentration of $2-3 \times 10^{4}$ cells $\mathrm{mL}^{-1}$ and transferred to $35 \mathrm{~mL}$ quartz tubes. Each tube was injected with $100 \mu \mathrm{L}-5 \mu \mathrm{Ci}(0.185 \mathrm{MBq}) \mathrm{NaH}^{14} \mathrm{CO}_{3}$ solution (ICN Radiochemicals). Triplicate incubations were carried out for each treatment as mentioned above and, additionally, three tubes were wrapped in aluminum foil and incubated as a dark control. The cells were collected on Whatman GF/F glass filters either immediately after $1 \mathrm{~h}$ exposure to the solar simulator or after a period of recovery under their growth light for another hour. The filters were put into $20 \mathrm{~mL}$ scintillation vials, fumed with $\mathrm{HCl}$ for $12 \mathrm{~h}$ and then dried for $6 \mathrm{~h}$ at $45^{\circ} \mathrm{C}$ to expel the non-fixed inorganic carbon as $\mathrm{CO}_{2}$. Scintillation cocktail ( $3 \mathrm{~mL}$ of Tri-Carb 2800TR, Perkin Elmer ${ }^{\circledR}$ ) was added to the vials, and radioactivity in the vials counted with a liquid scintillation counter (LS 6500, Beckman Coulter, USA). Carbon fixation rates were calculated from these values and are presented on a per cell or per Chl $a$ basis.

\subsection{Measurement of chlorophyll fluorescence}

For chlorophyll fluorescence measurements, cell collection and radiation treatments were carried out as described above. The effective quantum yield was measured every $20 \mathrm{~min}$ ei- 
ther during the solar simulator exposure or during recovery under the growth light level.

The effective quantum yield and non-photochemical quenching (NPQ) parameters were calculated according to Genty et al. (1990) as yield $=\left(F_{\mathrm{m}}^{\prime}-F_{t}\right) / F_{\mathrm{m}}^{\prime}$ and $\mathrm{NPQ}=$ $\left(F_{\mathrm{m}}-F_{\mathrm{m}}^{\prime}\right) / F_{\mathrm{m}}^{\prime}$, respectively, where $F_{\mathrm{m}}$ is the maximum fluorescence yield after $15 \mathrm{~min}$ dark adaptation, $F_{\mathrm{m}}^{\prime}$ is the light-adapted maximal chlorophyll fluorescence yield measured during the exposures and $F_{t}$ is the steady fluorescence level during the exposures. The actinic light was set at the growth light level, and the saturating pulse $\left(5000 \mu \mathrm{mol}\right.$ photons $\left.\mathrm{m}^{-2} \mathrm{~s}^{-1}\right)$ lasted for $0.8 \mathrm{~s}$.

Repair $(r)$ and damage $(k)$ rates during the $60 \mathrm{~min}$ exposure period in the presence of UV were calculated using the Kok model (Heraud and Beardall, 2000): $P / P_{\text {initial }}=$ $r /(k+r)+[k /(k+r)] e^{-(k+r) t}$, where $P_{\text {initial }}$ and $P$ were the yield values at the beginning and at exposure time $t$.

During the recovery period, the exponential rate constant for recovery $(R)$ was calculated from the following equation: $y=y_{\mathrm{o}}+b \times[1-\exp (-R \times t)]$, where $y$ represents the yield value at time $t, y_{\mathrm{o}}$ is the starting value before recovery and $b$ is a constant.

The relative inhibitions of carbon fixation or yield caused by UVA or UVB were calculated as follows:

$$
\begin{aligned}
& \mathrm{Inh}_{\mathrm{UVR}}=\left(P_{\mathrm{PAR}}-P_{\mathrm{PAB}}\right) / P_{\mathrm{PAR}} \times 100 \%, \\
& \mathrm{Inh}_{\mathrm{UVA}}=\left(P_{\mathrm{PAR}}-P_{\mathrm{PA}}\right) / P_{\mathrm{PAR}} \times 100 \%, \\
& \mathrm{Inh}_{\mathrm{UVB}}=\mathrm{Inh}_{\mathrm{UVR}}-\mathrm{Inh}_{\mathrm{UVA}} ;
\end{aligned}
$$

where $P_{\mathrm{PAR}}, P_{\mathrm{PA}}$ and $P_{\mathrm{PAB}}$ represent carbon fixation or yield values under PAR, PAR + UVA, PAR + UVA + UVB treatments, respectively.

\subsection{Cells counts and chlorophyll $a$ measurements}

The cells were counted using a $\mathrm{Z} 2^{\mathrm{TM}}$ Coulter Counter (Beckman, USA). Where needed, we used the values for chlorophyll $a$ (Chl $a$ ) contents of the cells grown under the same $\mathrm{CO}_{2}$ and nitrate levels reported previously (Li et al., 2012a).

\subsection{Total protein content, superoxide dismutase (SOD) and catalase (CAT) measurements}

To determine the total protein content and activities of superoxide dismutase (SOD) and catalase (CAT), cells were collected, in the middle of the light phase, onto a polycarbonate membrane $(0.22 \mu \mathrm{m}$, Whatman $)$ under vacuum at a pressure of less than $0.01 \mathrm{MPa}$ and washed into a $1 \mathrm{~mL}$ centrifuge tube with phosphate buffer ( $\mathrm{pH}$ 7.6). The enzyme extractions were carried out in $0.6 \mathrm{~mL}$ phosphate buffer ( $\mathrm{pH}$ 7.6) that contained $50 \mathrm{mM} \mathrm{KH} \mathrm{KO}_{4}, 1 \mathrm{mM}$ ethylenediaminetetraacetic acid (EDTA), $0.1 \%$ Triton X-100 and $1 \%(w / v)$ polyvinylpolypyrrolidone. The cells were broken by sonication in an ice-water bath $\left(4^{\circ} \mathrm{C}\right)$, and the homogenized extract was centrifuged at $12000 \mathrm{~g}\left(4^{\circ} \mathrm{C}\right)$ for $10 \mathrm{~min}$ before the activities of SOD and CAT were tested with SOD and
CAT Assay Kits (Nanjing Jiancheng Biological Engineering Company, China). One unit of SOD was defined as the amount causing a $50 \%$ inhibition of nitroblue tetrazolium (NBT) reduction (Wang and Wang, 2010). One unit of CAT activity was defined as the amount required to decompose $1 \mu \mathrm{mol} \mathrm{H}_{2} \mathrm{O}_{2}$ per second. The SOD and CAT activities were expressed as $\mathrm{U} \mathrm{mg}^{-1}$ protein and per $10^{6}$ cells (Fig. S1 in the Supplement). The total protein content was determined according to Bradford (1976) using bovine serum albumin as the standard.

\subsection{Statistical analyses and calculations}

One-way analysis of variance (ANOVA) was used, followed by a multiple comparison using a Tukey test to establish differences among the treatments. Interactive effects among $\mathrm{CO}_{2}, \mathrm{NO}_{3}^{-}$and UVR on carbon fixation and yield were determined using a two- or three-way ANOVA to establish significant differences among the variables.

\section{Results}

\subsection{Carbon fixation}

Carbon fixation was significantly inhibited by UVR in both $\mathrm{HN}$ and LN-grown cells on either a per cell or per Chl $a$ basis (Fig. 1). Under the HN conditions, the carbon fixation rates of LC and $\mathrm{HC}$ cultures, compared to that of the PAR alone treatment, were inhibited by $29.4 \%(P=$ $0.0002)$ and $36.7 \%(P<0.0001)$ in the presence of UVA (PA treatment: PAR + UVA), and by $47.7 \%(P<0.0001)$ and $46.1 \%(P=0.0029)$ with both UVA and UVB (PAB, PAR + UVA + UVB) (Fig. 1a and c). However, the carbon fixation per cell in the LC-grown cells was $10.0 \%(P=$ 0.0058 ) higher in those exposed to PA, and fixation based on $\mathrm{Chl} a$ was higher under the PAR alone or PA treatments, by about $8.4(P=0.0253)$ and $17.9 \%(P=0.005)$ compared to that of the HC-grown cells. For PAB treatments, there were no significant differences between the HC- and LC-grown cells (Fig. 1a and c).

Under LN conditions, carbon fixation rates of LC- and HC-grown cells were decreased by $14.7(P=0.0039)$ and $1.1 \%(P=0.8658)$ in the presence of UVA (PA) and by $23.3(P=0.0019)$ and $27.3 \%(P=0.0123)$ with UVA and UVB (PAB) treatments, respectively (Fig. 1b and d), compared with that of PAR alone treatment. This indicates that both UVA and UVB resulted in significant impacts on the LN-grown cells under LC, but only UVB brought about a significant reduction of the rate under HC. In the PA treatment, the HC-LN cells fixed carbon at a rate $21.7 \%(P=0.0071)$ higher than in the LC-LN cells (Fig. 1b), however, there were no significant differences between $\mathrm{HC}$ and LC cells in the PAR and the PAB treatments under $\mathrm{N}$ limitation. Under the $\mathrm{LN}$ level, the carbon fixation rate per $\mathrm{Chl} a$ was about 


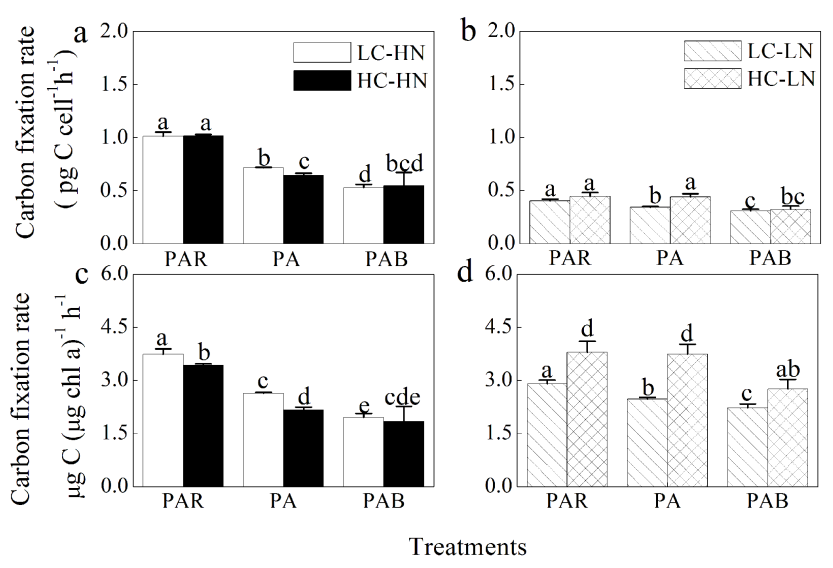

Figure 1. Photosynthetic carbon fixation rates of $P$. tricornutum under different treatments. Photosynthetic carbon fixation rates of $P$. tricornutum cells represented as rates $(\mathbf{a}, \mathbf{b})$ per cell and (c, d) per Chl $a$ grown at ambient $(390 \mu \mathrm{atm}, \mathrm{LC})$ or elevated $\mathrm{CO}_{2}$ (1000 $\mu \mathrm{atm}, \mathrm{HC})$ under $\mathrm{NO}_{3}^{-}$-replete $\left(110 \mu \mathrm{mol} \mathrm{L}{ }^{-1}, \mathrm{HN}\right)(\mathbf{a}, \mathbf{c})$ or $\mathrm{NO}_{3}^{-}$-limited conditions $\left(10 \mu \mathrm{molL} \mathrm{L}^{-1}, \mathrm{LN}\right)$; (b, d) when exposed to PAR, PAR + UVA (PA) and PAR + UVA + UVB (PAB) for $60 \mathrm{~min}$, respectively. Vertical bars indicate $\pm \mathrm{SD}$; the means and standard deviations were based on three replicates. The different lowercase letters indicate significant differences between different treatments at $P<0.05$ level.

$30.8(P=0.01), 51.6(P=0.0013)$ and $24.0 \%(P=0.03)$ higher in HC-grown than in LC-grown cells (Fig. 1d).

\subsection{Photochemical quantum yield}

When exposed to different irradiation treatments, photochemical quantum yields in the cells grown under either $\mathrm{HC}$ or LN conditions showed similar patterns to those grown at LC and HN conditions (Fig. 2), decreasing rapidly during the initial $20 \mathrm{~min}$ and leveling off after 40 to $60 \mathrm{~min}$. Under $\mathrm{HN}$ conditions, the yield in the HC-grown cells decreased to a similar level among the treatments (PAR, $P=0.1568$; PA, $P=0.0879$; PAB, $P=0.1341)$ as that in the LC treatments (Fig. 2a and b). Under the LN condition, the yield decreased to much lower levels compared to those under $\mathrm{HN}$ treatments (Fig. 2c and d). Cells exposed to all treatments showed recovery of the yield, under their growth light $\left(70 \mu \mathrm{mol}\right.$ photons $\left.\mathrm{m}^{-2} \mathrm{~s}^{-1}\right)$, to approximately their initial levels in about $80 \mathrm{~min}$ (Fig. 2).

\subsection{UVA- and UVB-induced inhibition of photosynthetic performance}

While UVA induced significantly higher $(P=0.0114)$ inhibition of photosynthetic carbon fixation in the $\mathrm{HC}-\mathrm{HN}$ grown cells, but lower $(P=0.0038)$ in the HC-LN-grown cells (Fig. 3a and b), it did not cause significant changes in the yield between the HC- and LC-grown cells (HN, $P=0.1375 ; \mathrm{LN}, P=0.0500$ ) (Fig. $3 \mathrm{c}$ and d). While the

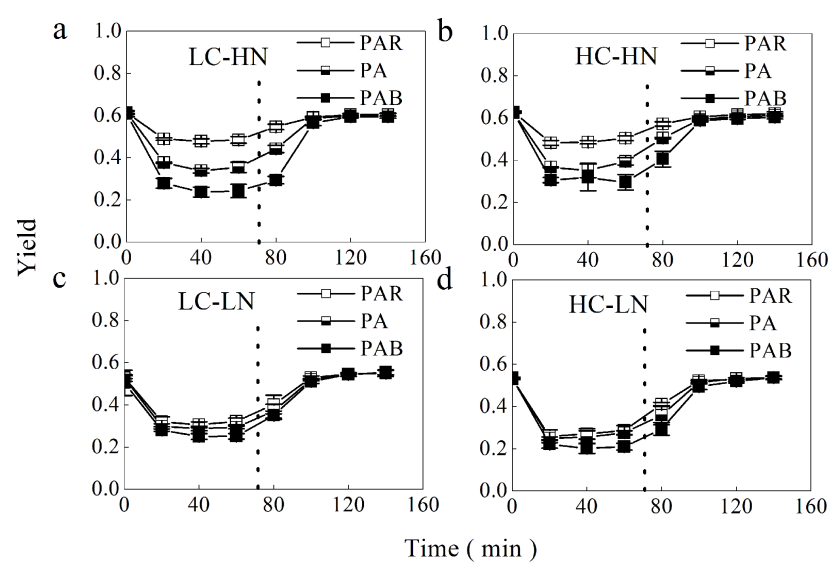

Figure 2. The effective quantum yield of $P$. tricornutum under different treatments. Changes of effective quantum yield in $P$. tricornutum cells at ambient ( $390 \mu \mathrm{atm}, \mathrm{LC})$ or elevated $\mathrm{CO}_{2}(1000 \mu \mathrm{atm}$, $\mathrm{HC})$ under (a, b) $\mathrm{NO}_{3}^{-}$-replete $\left(110 \mu \mathrm{mol} \mathrm{L}^{-1}, \mathrm{HN}\right)$ and (c, d) $\mathrm{NO}_{3}^{-}$-limited $\left(10 \mu \mathrm{mol} \mathrm{L}{ }^{-1}, \mathrm{LN}\right)$ conditions when exposed to PAR, $\mathrm{PAR}+\mathrm{UVA}(\mathrm{PA})$ and PAR + UVA + UVB (PAB) for $60 \mathrm{~min}$ and another $80 \mathrm{~min}$ under the growth light level (the time of the switch to growth light levels is indicated by the dashed line), respectively. The irradiance intensities under solar simulator or growth light were the same as mentioned above. Vertical bars show mean $\pm \mathrm{SD}, n=3$.

contribution of UVB did not induce significant inhibition of either carbon fixation $(P=0.2308)$ or yield $(P=0.5319)$ in the HN-grown cells, under both the HC and LC conditions (Fig. 3a and c), it caused significantly higher inhibition of the photosynthetic rate (by $203.3 \%, P=0.0006$ ) and the yield (by $76.8 \%, P=0.0451$ ) in the HC-grown than the LC-grown cells under $\mathrm{NO}_{3}^{-}$-limited conditions (Fig. $3 \mathrm{~b}$ and d). Interactive effects among $\mathrm{CO}_{2}, \mathrm{NO}_{3}^{-}$and radiation treatments on yield were significant (Table 1).

\subsection{Repair, damage rates and constant for recovery rate}

The HC-grown cells had higher rates of damage, $k$, than the LC-grown cells under nitrogen limitation but not under N-replete conditions (HN, $P=0.2109 ; \mathrm{LN}, P=0.0092$; Table 2). No effect was observed for repair rates $r$ (HN, $P=0.1655$; LN, $P=0.5276$; Table 2). The repair : damage ratios $(r / k)$ in the HC-grown cells showed a $21.0 \%$ (but statistically insignificant) increase under $\mathrm{HN}(P=0.3450)$ but decreased significantly by $31.1 \%$ under $\mathrm{LN}(P=0.0320)$ conditions, compared to the LC-grown cells, respectively (Table 2). Under the low PAR, the exponential rate constant for recovery $(R)$ showed dependency on previous light treatments with a lowered rate in the cells exposed to UVR, while $\mathrm{HC}$ stimulated the rate under the $\mathrm{HN}$ but not LN conditions (Table 3). Obviously, the cells exposed to the radiation treatments with UVB took longer $(P<0.05)$ to recover their photochemical yield, and pre-exposure to UVA had lit- 
Table 1. Interactive effects among $\mathrm{NO}_{3}^{-}$concentrations, $\mathrm{CO}_{2}$ levels and radiation treatments. Two or three way ANOVA analysis of individual and interactive effects among $\mathrm{NO}_{3}^{-}$concentrations, $\mathrm{CO}_{2}$ levels and radiation treatments. The asterisks indicate significance at $P<0.05$. Where "Ni" indicates nitrate, "OA" $\mathrm{CO}_{2} / \mathrm{pH}$, "Rad-Treat" radiation treatments, "Inh-C" inhibition of carbon fixation and "Inh-yield" inhibition of yield.

\begin{tabular}{lrrrrrrr}
\hline Parameter & Ni & OA & Rad-Treat & $\begin{array}{r}\text { Ni \& } \\
\text { OA }\end{array}$ & $\begin{array}{r}\text { Ni \& } \\
\text { Rad-Treat }\end{array}$ & $\begin{array}{r}\text { OA \& } \\
\text { Rad-Treat }\end{array}$ & $\begin{array}{r}\text { Ni, OA \& } \\
\text { Rad-Treat }\end{array}$ \\
\hline Carbon fixation & $*$ & $*$ & $*$ & $*$ & $*$ & $*$ \\
Inh-C & $*$ & $*$ & $*$ & & $*$ & $*$ \\
Yield & $*$ & & $*$ & $*$ & $*$ & \\
Inh-yield & $*$ & $*$ & $*$ & $*$ & \\
NPQ & $*$ & $*$ & & $*$ & \\
\hline
\end{tabular}

Table 2. The PSII damage $(k)$ and repair $(r)$ rate constants $\left(\mathrm{min}^{-1}\right)$ in Phaeodactylum tricornutum cells grown in LC-HN, LC-LN, HC-HN and HC-LN during the 60 min exposures to PAR + UVA + UVB $\left(44.11+14.19+0.75 \mathrm{Wm}^{-2}\right)$. Parameters of repair and damage rates were calculated based on Fig. 2 according to Heraud and Beardall (2000). SD was for triplicate cultures. Treatments with the same lowercase superscript letters mean the difference is not significant. In contrast, treatments with different lowercase superscript letters indicate the difference is significant $(P<0.05$ level).

\begin{tabular}{lrlll}
\hline & $R^{2}$ for fit & Repair rate $(r)$ & Damage rate $(k)$ & $r / k$ \\
\hline LC-HN & $>0.99$ & $0.044 \pm 0.007^{\mathrm{a}}$ & $0.068 \pm 0.007^{\mathrm{a}}$ & $0.666 \pm 0.216^{\mathrm{ab}}$ \\
HC-HN & $>0.99$ & $0.064 \pm 0.019^{\mathrm{ab}}$ & $0.079 \pm 0.010^{\mathrm{ab}}$ & $0.806 \pm 0.145^{\mathrm{ab}}$ \\
LC-LN & $>0.99$ & $0.054 \pm 0.012^{\mathrm{ab}}$ & $0.062 \pm 0.008^{\mathrm{a}}$ & $0.854 \pm 0.138^{\mathrm{a}}$ \\
HC-LN & $>0.99$ & $0.059 \pm 0.005^{\mathrm{b}}$ & $0.095 \pm 0.010^{\mathrm{b}}$ & $0.588 \pm 0.073^{\mathrm{b}}$ \\
\hline
\end{tabular}

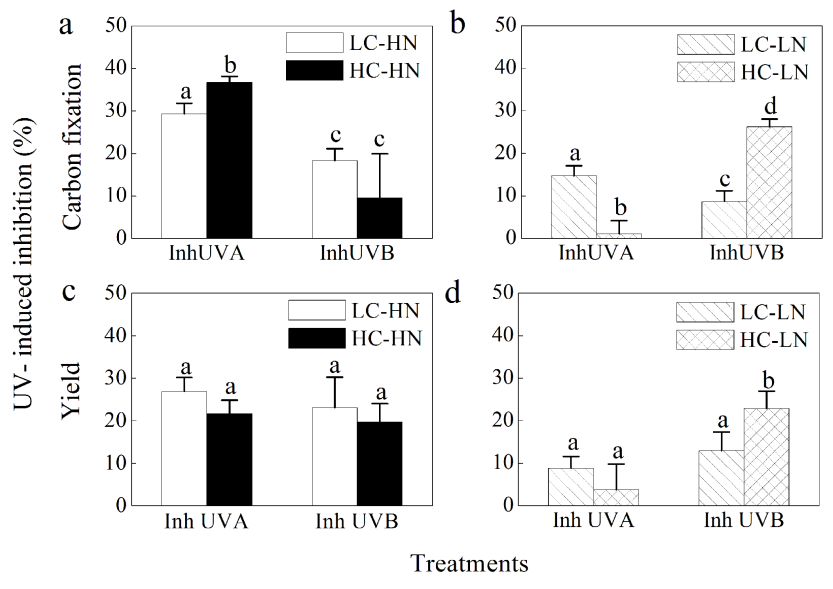

Figure 3. UV-induced inhibition of carbon fixation and PSII activity. UVA- and UVB-induced inhibition of (a, b) photosynthetic carbon fixation and (c, d) PSII of P. tricornutum cells grown at ambient $(390 \mu \mathrm{atm}, \mathrm{LC})$ or elevated $\mathrm{CO}_{2}(1000 \mu \mathrm{atm}, \mathrm{HC})$ under (a, c) $\mathrm{NO}_{3}^{-}$-replete $\left(110 \mu \mathrm{mol} \mathrm{L}^{-1}, \mathrm{HN}\right)$ and $(\mathbf{b}, \mathbf{d}) \mathrm{NO}_{3}^{-}$-limited $\left(10 \mu \mathrm{mol} \mathrm{L}{ }^{-1}, \mathrm{LN}\right)$ conditions when exposed to PAR, PAR + UVA (PA) and PAR + UVA + UVB (PAB) for $60 \mathrm{~min}$, respectively. The irradiance intensity under solar simulator was the same as mentioned above. Vertical bars are means $\pm \mathrm{SD}, n=3$, the different letters indicate significant differences between different treatments at $P<0.05$ level.
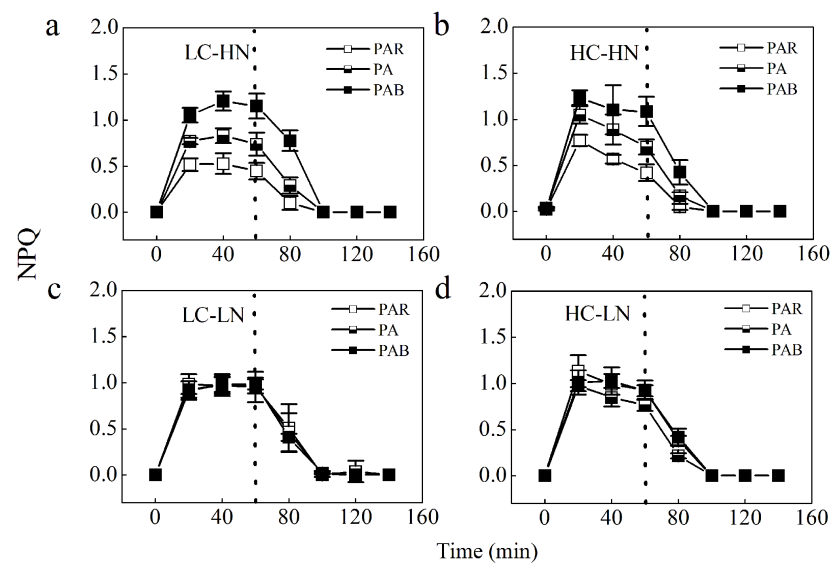

Figure 4. Non-photochemical quenching (NPQ) of P. tricornutum under different treatments. NPQ of $P$. tricornutum grown at ambient $(390 \mu \mathrm{atm}, \mathrm{LC})$ or elevated $\mathrm{CO}_{2}(1000 \mu \mathrm{atm}, \mathrm{HC})$ under (a, b) $\mathrm{NO}_{3}^{-}$-replete $(110 \mu \mathrm{mol} \mathrm{L}-1, \mathrm{HN})$ and $(\mathbf{c}, \mathbf{d}) \mathrm{NO}_{3}^{-}$-limited $\left(10 \mu \mathrm{mol} \mathrm{L} \mathrm{L}^{-1}, \mathrm{LN}\right)$ conditions when exposed to PAR, PAR + UVA (PA) and PAR + UVA + UVB (PAB) for $60 \mathrm{~min}$ and another $80 \mathrm{~min}$ under the growth light level, respectively. The irradiance intensities under solar simulator or growth light were the same as mentioned above. Vertical bars means $\pm \mathrm{SD}, n=3$. 
Table 3. The exponential rate constant for recovery $\left(R, \min ^{-1}\right)$ under growth light after 60 min exposure to solar radiation with or without UV. Different letters of superscripts indicate significant differences between the $\mathrm{CO}_{2}$ and $\mathrm{NO}_{3}^{-}$treatments at $P<0.05$.

\begin{tabular}{lrrrr}
\hline & LC-HN & LC-LN & HC-HN & HC-LN \\
\hline PAR & $0.038 \pm 0.006^{\mathrm{ab}}$ & $0.029 \pm 0.011^{\mathrm{b}}$ & $0.043 \pm 0.009^{\mathrm{a}}$ & $0.038 \pm 0.002^{\mathrm{ab}}$ \\
PA & $0.028 \pm 0.002^{\mathrm{a}}$ & $0.023 \pm 0.007^{\mathrm{a}}$ & $0.037 \pm 0.002^{\mathrm{b}}$ & $0.027 \pm 0.008^{\mathrm{ab}}$ \\
PAB & $0.019 \pm 0.002^{\mathrm{a}}$ & $0.024 \pm 0.001^{\mathrm{b}}$ & $0.029 \pm 0.003^{\mathrm{c}}$ & $0.021 \pm 0.003^{\mathrm{d}}$ \\
\hline
\end{tabular}

Table 4. The recovery time to half maximal yield values under growth light after 60 min exposure to solar radiation with or without UV. Different letters of superscripts indicate significant differences between the radiation treatments at $P<0.05$.

\begin{tabular}{lrrrr}
\hline & $\begin{array}{r}\text { LC-HN } \\
(\mathrm{min})\end{array}$ & $\begin{array}{r}\text { LC-LN } \\
(\mathrm{min})\end{array}$ & $\begin{array}{r}\text { HC-HN } \\
(\mathrm{min})\end{array}$ & $\begin{array}{r}\text { HC-LN } \\
(\mathrm{min})\end{array}$ \\
\hline PAR & $16.78 \pm 2.94^{\mathrm{a}}$ & $20.81 \pm 5.93^{\mathrm{a}}$ & $15.41 \pm 2.57^{\mathrm{ab}}$ & $16.79 \pm 0.64^{\mathrm{a}}$ \\
PA & $20.38 \pm 1.28^{\mathrm{a}}$ & $23.36 \pm 4.47^{\mathrm{a}}$ & $16.83 \pm 0.67^{\mathrm{a}}$ & $21.66 \pm 4.52^{\mathrm{ab}}$ \\
PAB & $25.82 \pm 1.51^{\mathrm{b}}$ & $22.73 \pm 1.25^{\mathrm{a}}$ & $20.05 \pm 1.78^{\mathrm{b}}$ & $24.64 \pm 1.57^{\mathrm{b}}$ \\
\hline
\end{tabular}

tle $(P>0.05)$ effect on the recovery; HC-HN-grown cells had faster $(P<0.05)$ photochemical recovery (Table 4$)$.

\subsection{Non-photochemical quenching (NPQ)}

Non-photochemical quenching (NPQ) showed the opposite pattern of change to yield during both the exposure and recovery periods (Fig. 4). Under HN conditions, HC treatments triggered the highest NPQ within 20 min, while NPQ reached its maximal values at 40 min under the ambient (LC) $\mathrm{CO}_{2}$ level (Fig. 4a and b). Similar trends were found in both the LN- and HN-grown cells regardless of the radiation treatments (Fig. 4). Both UVA and UVB caused additional $(P<0.05)$ rises in NPQ in $\mathrm{HN}$-grown cells regardless of the $\mathrm{CO}_{2}$ levels (Fig. 4a and b). However, neither UVA nor UVB induced significant $(P>0.05)$ change in NPQ in LN-grown cells, regardless of the $\mathrm{CO}_{2}$ levels (Fig. 4c and d). Lower NPQ values were found in HN-grown cells compared with LN, under either PAR alone or PAR + UVA treatments. The addition of UVB, however, resulted in an approximately $17.0 \%$ higher, but statistically insignificant (LC, $P=0.1150 ; \mathrm{HC}, P=0.1660$ ), increase of NPQ in HNgrown compared to $\mathrm{LN}$-grown cells. Transfer to the growth light level without UV, to allow for recovery, led to a rapid decline of NPQ with time. For the cells that were pre-exposed to the PAR + UVA + UVB treatment, relaxation of NPQ during the recovery period showed no difference $(P>0.05)$ between HC- and LC-grown cells except that NPQ in the HCHN-grown cells declined faster $(P=0.0242)$ than in LCHN cells. Two-way ANOVA showed that both nitrogen levels and radiation treatments individually, and also interactively, affected the NPQ (Table 1).

\subsection{Protein content, SOD and CAT activities}

Protein contents were enhanced in $\mathrm{HN}$ cultures under both LC $\left(3.21 \pm 0.98 \mathrm{pg} \mathrm{cell}^{-1}\right)$ and HC $\left(3.38 \pm 1.35 \mathrm{pg} \mathrm{cell}^{-1}\right)$ conditions, compared with LN-grown cells (LC, $2.58 \pm 0.46 \mathrm{pg} \mathrm{cell}^{-1} ; \mathrm{HC}, 2.28 \pm 0.68 \mathrm{pg} \mathrm{cell}^{-1}$ ), though statistically there were no significant differences among the treatments $(P=0.4296)$ (Fig. 5a). There was no significant difference in protein content between LC and $\mathrm{HC}$ treatments at a given $\mathrm{NO}_{3}^{-}$concentration. However, $\mathrm{NO}_{3}^{-}$limitation enhanced SOD (LC, by $62.5 \%, P=0.0004$; HC, by $72.5 \%$, $P=0.0007$ ) and CAT (LC, by $67.5 \%, P=0.0759 ; \mathrm{HC}$, by $67.1 \%, P=0.0747$ ) activities in both LC- and HC-grown cells, when based on protein content (Fig. $5 b$ and c), though such enhancement was insignificant $(P>0.1)$ when normalized to per cell (Fig. S1).

\section{Discussion}

This study shows that nitrate limitation interacts with OA to affect the overall impacts of solar UVR on the diatom $P$. tricornutum. OA and UVB caused significantly higher inhibition of the photosynthetic rate and the quantum yield under LN than under HN conditions. Interactive effects of reduced nitrate availability and OA increased protein-based activity of superoxide dismutase (SOD) and catalase (CAT) but decreased the rate of repair of PSII from UV-induced damage. OA appeared to counteract UVB-induced damage under $\mathrm{NO}_{3}^{-}$-replete conditions, but when combined with decreased availability of nitrate, it increased the diatom's sensitivity to UVR.

Most diatoms have evolved $\mathrm{CO}_{2}$ concentrating mechanisms (CCMs) as a response to low availability of $\mathrm{CO}_{2}$ in present-day oceans (Raven et al., 2011). Increasing $p \mathrm{CO}_{2}$ may, to some extent, benefit marine phytoplankton due to in- 
a

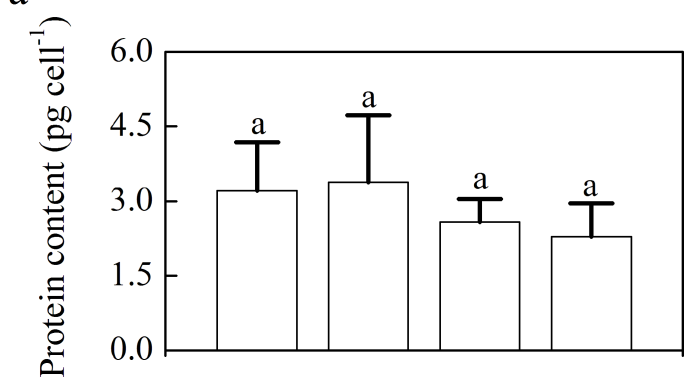

b

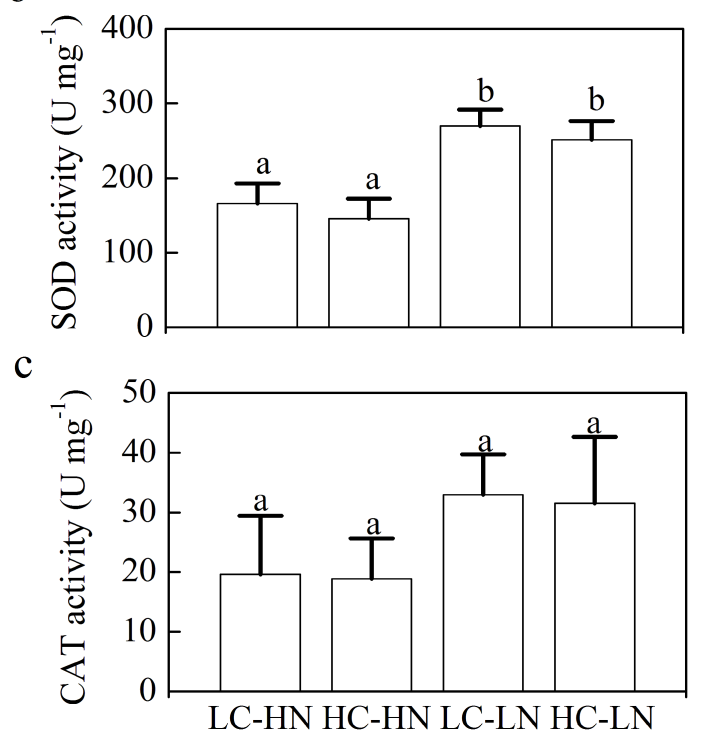

Figure 5. Protein contents, SOD and CAT activities of $P$. tricornutum under different treatments. (a) Protein contents, (b) SOD and (c) CAT activities (represented as per milligram protein) of P. tricornutum grown at ambient $(390 \mu \mathrm{atm}, \mathrm{LC})$ or elevated $\mathrm{CO}_{2}$ (1000 $\mu$ atm, HC) under $\mathrm{NO}_{3}^{-}$-replete $\left(110 \mu \mathrm{mol} \mathrm{L}{ }^{-1}, \mathrm{HN}\right)$ or $\mathrm{NO}_{3}^{-}$limited $\left(10 \mu \mathrm{mol} \mathrm{L}^{-1}, \mathrm{LN}\right)$ conditions. The different letters above each column indicate significant differences between different treatments at $P<0.05$ level. Vertical bars show mean $\pm \mathrm{SD}$, except the CAT value in $\mathrm{HC}-\mathrm{LN}$ for which there were only two replicates, other treatments used at least three replicates $(n=3-7)$.

creased availability of $\mathrm{CO}_{2}$ (Burkhardt et al., 2001; Rost et al., 2003). CCMs are known to be down-regulated under a $\mathrm{CO}_{2}$ level doubling that of the current ambient concentration, saving about $20 \%$ of the energy cost for active inorganic carbon acquisition in some diatoms (including $P$. tricornutum; Hopkinson et al., 2011). Such a down-regulation of CCMs was equally obvious in P. tricornutum grown under nitrate-limited or nitrate-replete conditions (Wu et al., 2010; Li et al., 2012a). However, this down-regulated CCM and its effects may be mediated by many other factors. A recent study found that different acclimation times (short term, 1516 generations and longer term, 33-57 generations) to increased $\mathrm{CO}_{2}$ and nitrate limitation may have different effects on the DIC and DIN uptake rate in the diatom Thalassiosira

pseudonana, with short-term acclimated cells showing a linear correlation with changes in $f \mathrm{CO}_{2}$, although this was not the case in long-term acclimated cells (Hennon et al., 2014). On the other hand, the down-regulation of CCM operation was recently shown to decrease the growth of three diatoms (Phaeodactylum tricornutum, Thalassiosira pseudonana and Skeletonema costatum) under high levels of sunlight but to enhance it under low light (Gao et al., 2012b). The growth rate of $P$. tricornutum under high $\mathrm{CO}_{2}(1000 \mu \mathrm{atm})$ decreased at light levels higher than $180 \mu \mathrm{mol} \mathrm{m} \mathrm{m}^{-2} \mathrm{~s}^{-1}$ to reach growth rate values lower than that of the low $\mathrm{CO}_{2}$-grown cells ( $\mathrm{Gao}$ et al., 2012b). In the present study, under the near-saturation light level (ca. $190 \mu \mathrm{mol}$ photons $\mathrm{m}^{-2} \mathrm{~s}^{-1}$ of PAR), photosynthetic carbon fixation rate per $\mathrm{Chl} a$ under nitrate-limited conditions were higher in the HC-grown cells. Obviously, the nutrient limitation influenced the effects of OA.

UVR is known to damage photosynthetic pigments and proteins (for example D1 and rubisco proteins; Zacher et al., 2007) and therefore can reduce the photosynthetic capacity of algae (Häder et al., 2011). UVA induced significantly higher inhibition of carbon fixation in HC-HN- than in LCHN-grown cells, reflecting a synergistic effect of UVA and OA; however, for the same cells, UVB induced no greater inhibition of the photosynthetic carbon fixation in HC compared to LC cells, which is in contrast to the findings reported in another study (Li et al., 2012b). Many studies have shown that the sensitivity of cells to high levels of PAR and UV under OA conditions could be stimulated and then induce higher inhibition rate of photosynthesis (Sobrino et al., 2008; Gao et al., 2012b; Xu and Gao, 2012). However, this phenomenon is not always found in all species especially when the intensity of PAR or UV is not that high. For example, a recent study reported that the unicellular chlorophyte (Dunaliella tertiolecta) acclimated with high $\mathrm{CO}_{2}$ under nutrient-replete conditions could alleviate the stress induced by high PAR and UV (García-Gómez et al., 2014). This could be due to energy saving as a result of down-regulation of CCM activity. However, in the present study, we did not find that the synergistic effects of OA and UVR induced a higher inhibition at the light intensity of PAR + UVA + UVB $\left(44.11+14.19+0.75 \mathrm{Wm}^{-2}\right)$ used, than found under LC. This may be due to the light intensity of PAR or UVR not being high enough to exceed the energy dissipating capacity of the cells. Furthermore, under high $N$ the nutrient supply would be sufficient to support the repair processes of UVor high-PAR-induced damage. In the LN-grown cells, UVB induced greater inhibition of both carbon fixation and yield, probably due to a decreased repair / damage ratio (Table 2) and decreased levels of both Chl $a$ and other light-harvesting pigments (Li et al., 2012a) since the (re)synthesis of both proteins and UV-screening compounds depends on nitrogen availability (Beardall et al., 2009, 2014). Such an inhibition by UVB in LN-grown cells was more pronounced under OA conditions (Fig. 3b and d), though UVB appeared to counteract the OA effect under the HN condition. When the 
cells are exposed to lower external $\mathrm{pH}$, they need additional energy to cope with the acid-base perturbation (Kanazawa and Kramer, 2002). By impairing photosynthesis, nitrogen limitation could decrease the supply of energy, especially in the presence of UVB (Döhler, 1998). Though SOD and CAT normalized per cell showed no change in all treatments (Fig. S1), the fact that nitrogen limitation led to decreased protein contents per cell and with higher activity of SOD and CAT (based on protein content) implies that these enzymes are preferentially retained in the face of decreasing protein per cell and thus reflects an enhanced defense strategy (Fig. 5), so that ROS that were formed under $\mathrm{N}$ limitation could be scavenged. The differential impacts of UVB on HN and LN-grown cells under the OA treatment could be due to differences in the repair and damage rates (Table 2) and differential stimulation of periplasmic proteins (Wu and Gao, 2009), which are important transporters of ions and play important roles in maintaining intracellular acid-base stability. On the other hand, $\mathrm{NO}_{3}^{-}$scarcity usually leads to an impaired PSII reaction center activity due to decreased synthesis of key proteins, therefore, leading to decreased quantum yields of PSII (Geider et al., 1993). In this study, P. tricornutum showed much lower yield (Fig. 2c and d), as well as NPQ, in the nitrogen-limited cells (Fig. $4 \mathrm{c}$ and d), indicating smaller functional PSII reaction centers and a lower heat dissipating capability, when combined with the OA treatment, consistent with these cells having the highest damage and the lowest repair (Table 2). In the HN-grown cells, better recovery of both photosynthetic carbon fixation (data not shown) and photochemical performance (Tables 3 and 4) under OA conditions could be attributed to faster repair rate of PSII and related metabolic up-regulations.

The results from the present work suggest that nutrient limitation can alter the effects of OA or UVR and their interactions. In the oligotrophic oceans, such as the surface mixed layers of the South China Sea (SCS), where averaged total inorganic nitrogen concentrations range from 0-20 $\mu \mathrm{mol}$, UVB and OA can act synergistically to bring about a higher inhibition of photosynthetic carbon fixation. Higher UVBinduced inhibition of photosynthesis was found in pelagic low-nutrient waters than in coastal waters in the SCS ( $\mathrm{Li}$ et al., 2011). With enhanced stratification and reduced thickness of the upper mixed layer due to ocean warming, fewer nutrients will be transported from deeper layers to the photic zones, and interactions of enhanced nutrient limitation, $\mathrm{OA}$ and increased solar exposures will become the main drivers influencing marine primary production (Gao et al., 2012a). For diatoms, such as $P$. tricornutum, $\mathrm{OA}$ and other ocean changes may result in transitions in their vertical and horizontal distributions and changes in phytoplankton community structure.

The Supplement related to this article is available online at doi:10.5194/bg-12-2383-2015-supplement.
Author contributions. K. Gao and W. Li conceived of and designed the experiments, W. Li performed the experiments. W. Li, K. Gao and $\mathrm{J}$. Beardall analyzed the data and wrote the paper.

Acknowledgements. This study was supported by National Natural Science Foundation $(41120164007,41430967)$, by the joint project of NSFC and Shandong Province (grant no. U1406403), Strategic Priority Research Program of CAS (grant no. XDA11020302), Program for Chang-jiang Scholars and Innovative Research Team (IRT_13R51), SOA (GASI-03-01-02-04) and China-Japan collaboration project from MOST (S2012GR0290). J. Beardall's work on climate change effects on algae has been funded by the Australian Research Council and his visit to Xiamen was supported by "111" project from Ministry of Education. We thank Yahe Li (Xiamen University, China) for her kind assistance during the experiments.

Edited by: A. Shemesh

\section{References}

Beardall, J., Sobrino, C., and Stojkovic, S.: Interactions between the impacts of ultraviolet radiation, elevated $\mathrm{CO}_{2}$, and nutrient limitation on marine primary producers, Photochem. Photobio. S., 8, 1257-1265, 2009.

Beardall, J., Stojkovic, S., and Gao, K.: Interactive effects of nutrient supply and other environmental factors on the sensitivity of marine primary producers to ultraviolet radiation: implications for the impacts of global change, Aquat. Biol., 22, 5-23, 2014.

Beman, J. M., Chow, C.-E., King, A. L., Feng, Y., Fuhrman, J. A., Andersson, A., Bates, N. R., Popp, B. N., and Hutchins, D. A.: Global declines in oceanic nitrification rates as a consequence of ocean acidification, P. Natl. Acad. Sci. USA, 108, 208-213, 2011.

Boyd, P. W.: Beyond ocean acidification, Nat. Geosci., 4, 273-274, 2011.

Bradford, M. M.: A rapid and sensitive method for the quantitation of microgram quantities of protein utilizing the principle of protein-dye binding, Anal. Biochem., 72, 248-254, 1976.

Buma, A. G. J., Boelen, P., and Jeffrey, W. H.: UVR-induced DNA damage in aquatic organisms. In: UV effects in aquatic organisms and ecosystems, edited by: Helbling, E. W. and Zagarese, H. E., T. Roy. Soc. Chem., Cambridge, UK, 291-327, 2003.

Burkhardt, S., Amoroso, G., Riebesell, U., and Sültemeyer, D.: $\mathrm{CO}_{2}$ and $\mathrm{HCO}_{3}^{-}$uptake in marine diatoms acclimated to different $\mathrm{CO}_{2}$ concentrations, Limnol. Oceanogr., 46, 1378-1391, 2001.

Cashmore, A. R.: The cryptochrome family of blue/UV-A photoreceptors, J. Plankton Res., 111, 267-270, 1998.

Cermeño, P., Dutkiewicz, S., Harris, R. P., Follows, M., Schofield, O., and Falkowski, P. G.: The role of nutricline depth in regulating the ocean carbon cycle, P. Natl. Acad. Sci. USA, 105, 2034420349, 2008.

Chen, S. and Gao, K.: Solar ultraviolet radiation and $\mathrm{CO}_{2}$-induced ocean acidification interacts to influence the photosynthetic performance of the red tide alga Phaeocystis globosa (Prymnesiophyceae), Hydrobiologia, 675, 105-117, 2011.

Dickson, A. G.: Standard potential of the reaction: $\mathrm{AgCl}(\mathrm{s})+1 / 2$ $\mathrm{H}_{2}(\mathrm{~g})=\mathrm{Ag}(\mathrm{s})+\mathrm{HCl}(\mathrm{aq})$, and the standard acidity constant of 
the ion $\mathrm{HSO}_{4}^{-}$in synthetic seawater from 273.15 to $318.15 \mathrm{~K}$, J. Chem. Thermodyn., 22, 113-127, 1990.

Döhler, G.: Effect of ultraviolet radiation on pigmentation and nitrogen metabolism of Antarctic phytoplankton and ice algae, J. Plant Physiol., 153, 603-609, 1998.

Doney, S. C., Fabry, V. J., Feely, R. A., and Kleypas, J. A.: Ocean acidification: The other $\mathrm{CO}_{2}$ problem, Annu. Rev. Mar. Sci., 1, 169-192, 2009.

$\mathrm{Fu}$, F., Place, A. R., Garcia, N. S., and Hutchins, D. A.: $\mathrm{CO}_{2}$ and phosphate availability control the toxicity of the harmful bloom dinoflagellate Karlodinium veneficum, Aquat. Microb. Ecol., 59, 55-65, 2010.

Gao, K.: Positive and negative effects of ocean acidification: Physiological responses of algae, Journal of Xiamen University (Natural Science), 50, 411-417, 2011.

Gao, K., Wu, Y., Li, G., Wu, H., Villafañe, V. E., and Helbling, E. W.: Solar UV radiation drives $\mathrm{CO}_{2}$ fixation in marine phytoplankton: a double-edged sword, Plant Physiol., 144, 54-59, 2007.

Gao, K., Li, P., Watanabe, T., and Helbling, E. W.: Combined effects of ultraviolet radiation and temperature on morphology, photosynthesis, and DNA of Arthrospira (Spirulina) platensis (Cynophyta), J. Phycol., 44, 777-786, 2008.

Gao, K., Helbling, E. W., Häder, D. P., and Hutchins, D. A.: Responses of marine primary producers to interactions between ocean acidification, solar radiation, and warming, Mar. Ecol. Prog. Ser., 470, 167-189, 2012a.

Gao, K., Xu, J., Gao, G., Li, Y., Hutchins, D. A., Huang, B., Wang, L., Zheng, Y., Jin, P., Cai, X., Häder, D. P., Li, W., Xu, K., Liu, N., and Riebesell, U.: Rising $\mathrm{CO}_{2}$ and increased light exposure synergistically reduce marine primary productivity, Nat. Clim. Change., 2, 519-523, 2012b.

García-Gómez, C., Gordillo, F. J., Palma, A., Lorenzo, M. R., and Segovia, M.: Elevated $\mathrm{CO}_{2}$ alleviates high PAR and UV stress in the unicellular chlorophyte Dunaliella tertiolecta, Photochem. Photobio. S., 13, 1347-1358, 2014.

Geider, R. J., Roche, J., Greene, R. M., and Olaizola, M.: Response of the photosynthetic apparatus of Phaeodactylum tricornutum (Bacillariophyceae) to nitrate, phosphate, or iron starvation, J. Phycol., 29, 755-766, 1993.

Genty, B., Harbinson, J., and Baker, N. R.: Relative quantum efficiencies of the two-photosystems of leaves in photorespiratory and non-photorespiratory conditions, Plant Physiol. Bioch., 28, 1-10, 1990.

Granum, E., Raven, J. A., and Leegood, R. C.: How do marine diatoms fix 10 billion tonnes of inorganic carbon per year?, Can. J. Bot., 83, 898-908, 2005.

Häder, D.-P., Helbling, E. W., Williamson, C. E., and Worrest, R. C.: Effects of UV radiation on aquatic ecosystems and interactions with climate change, Photochem. Photobio. S., 10, 242 260, 2011

Helbling, E. W., Gao, K., Gonçalves, R. J., Wu, H., and Villafañe, V. E.: Utilization of solar UV radiation by coastal phytoplankton assemblages off SE China when exposed to fast mixing, Mar. Ecol. Prog. Ser., 259, 59-66, 2003.

Hennon, G. M. M., Quay, P., Morales, R. L., Swanson, L. M., and Virginia Armbrust, E.: Acclimation conditions modify physiological response of the diatom Thalassiosira pseudonana to ele- vated $\mathrm{CO}_{2}$ concentrations in a nitrate-limited chemostat, J. Phycol., 50, 243-253, 2014.

Heraud, P. and Beardall, J.: Changes in chlorophyll fluorescence during exposure of Dunaliella tertiolecta to UV radiation indicate a dynamic interaction between damage and repair processes, Photosynth. Res., 63, 123-134, 2000.

Heraud, P., Roberts, S., Shelly, K., and Beardall, J.: Interactions between UV-B exposure and phosphorus nutrition. II. Effects on rates of damage and repair, J. Phycol., 41, 1212-1218, 2005.

Hessen, D. O., Leu, E., Færøvig, P. J., and Falk Petersen, S.: Light and spectral properties as determinants of $\mathrm{C}: \mathrm{N}: \mathrm{P}-$ ratios in phytoplankton, Deep-Sea Res. Part II, 55, 2169-2175, 2008.

Holm-Hansen, O. and Helbling, E. W.: Técnicas para la medición de la productividad primaria en el fitoplancton, in: Manual de métodos ficológicos, edited by: Alveal, K., Ferrario, M. E., Oliveira, E. C., and Sar, E., Universidad de Concepción, Concepción,Chile, 329-350, 1995.

Hopkinson, B. M., Xu, Y., Shi, D., McGinn, P. J., and Morel, F. M. M.: The effect of $\mathrm{CO}_{2}$ on the photosynthetic physiology of phytoplankton in the Gulf of Alaska, Limnol. Oceanogr., 55, 20112024, 2010.

Hopkinson, B. M., Dupont, C. L., Allen, A. E., and Morel, F. M. M.: Efficiency of the $\mathrm{CO}_{2}$-concentrating mechanism of diatoms, P. Natl. Acad. Sci., 108, 3830-3837, 2011.

IPCC: Workshop Report of the Intergovernmental Panel on Climate Change Workshop on Impacts of Ocean Acidification on Marine Biology and Ecosystems, edited by: Field, C. B., Barros, V., Stocker, T. F., Qin, D., Mach, K. J., Plattner, G.-K., Mastrandrea, M. D., Tignor, M., and Ebi, K. L., IPCC Working Group II Technical Support Unit, Carnegie Institution, Stanford, California, USA, 2011.

Kanazawa, A. and Kramer, D. M.: In vivo modulation of nonphotochemical exciton quenching (NPQ) by regulation of the chloroplast ATP synthase, P. Natl. Acad. Sci., 99, 12789-12794, 2002.

Kim, J. M., Lee, K., Shin, K., Kang, J. H., Lee, H. W., Kim, M., Jang, P. G., and Jang, M. C.: The effect of seawater $\mathrm{CO}_{2}$ concentration on growth of a natural phytoplankton assemblage in a controlled mesocosm experiment, Limnol. Oceanogr., 51, 1629 1636, 2006.

King, A. L., Sañudo-Wilhelmy, S. A., Leblanc, K., Hutchins, D. A., and $\mathrm{Fu}, \mathrm{F} . \mathrm{C} \mathrm{CO}_{2}$ and vitamin $\mathrm{B}_{12}$ interactions determine bioactive trace metal requirements of a subarctic Pacific diatom, ISME, 5, 1388-1396, 2011.

Leonardos, N. and Geider, R. J.: Elevated atmospheric carbon dioxide increases organic carbon fixation by Emiliania Huxleyi (Haptophyta), under nutrient-limited high-light conditions, J. Phycol., 41, 1196-1203, 2005.

Lewis, E. and Wallace, D. W. R.: Program developed for $\mathrm{CO}_{2}$ system calculations. In: ORNL/CDIAC-105, Carbon Dioxide Information Analysis Center, Oak Ridge National Laboratory, US Department of Energy, Oak Ridge, Tennessee, 1998.

Li, G., Gao, K., and Gao, G.: Differential impacts of solar UV radiation on photosynthetic carbon fixation from the coastal to offshore surface waters in the South China Sea, Photochem. Photobiol., 87, 329-334, 2011.

Li, W., Gao, K., and Beardall, J.: Interactive effects of ocean acidification and nitrogen-limitation on the diatom Phaeodactylum tricornutum, PLoS One, 7, e51590, doi10.1371/journal.pone.0051590, 2012a. 
Li, Y., Gao, K., Villafañe, V. E., and Helbling, E. W.: Ocean acidification mediates photosynthetic response to UV radiation and temperature increase in the diatom Phaeodactylum tricornutum, Biogeosciences, 9, 3931-3942, doi:10.5194/bg-9-39312012, 2012b.

Litchman, E., Neale, P. J., and Banaszak, A. T.: Increased sensitivity to ultraviolet radiation in nitrogen-limited dinoflagellates: Photoprotection and repair, Limnol. Oceanogr., 47, 86-94, 2002.

Morel, F. M. M., Rueter, J. G., Anderson, D. M., and Guillard, R. R. L.: Aquil: A chemically defined phytoplankton culture medium for trace metal studies, J. Phycol., 15, 135-141, 1979.

Neale, P., Sobrino, C., Segovia, M., Mercado, J., Leon, P., Cortés, M., Tuite, P., Picazo, A., Salles, S., and Cabrerizo, M.: Effect of $\mathrm{CO}_{2}$, nutrients and light on coastal plankton. I. Abiotic conditions and biological responses, Aquat. Biol., 22, 25-41, 2014.

Nielsen, E. S.: The use of radioactive carbon $\left(\mathrm{C}^{14}\right)$ for measuring organic production in the sea, J. Conseil, 18, 117-140, 1952.

Orr, J. C., Fabry, V. J., Aumont, O., Bopp, L., Doney, S. C., Feely, R. A., Gnanadesikan, A., Gruber, N., Ishida, A., Joos, F., Key, R. M., Lindsay, K., Maier-Reimer, E., Matear, R., Monfray, P., Mouchet, A., Najjar, R. G., Plattner, G. K., Rodgers, K. B., Sabine, C. L., Sarmiento, J. L., Schlitzer, R., Slater, R. D., Totterdell, I. J., Weirig, M. F., Yamanaka, Y., and Yool, A.: Anthropogenic ocean acidification over the twenty-first century and its impact on calcifying organisms, Nature, 437, 681-686, 2005.

Pörtner, H. O. and Farrell, A. P.: Physiology and climate change, Science, 322, 690-692, 2008.

Raven, J. A., Giordano, M., Beardall, J., and Maberly, S. C.: Algal and aquatic plant carbon concentrating mechanisms in relation to environmental change, Photosynth. Res., 109, 281-296, 2011.

Riebesell, U. and Tortell, P. D.: Effects of ocean acidification on pelagic organisms and ecosystems, in: Ocean acidification, edited by: Gattuso, J.-P. and Hansson, L., Oxford University Press, New York, 99-121, 2011.

Riebesell, U., Wolf-Gladrow, D. A., and Smetacek, V.: Carbon dioxide limitation of marine phytoplankton growth rates, Nature, 361, 249-251 1993.

Rost, B., Riebesell, U., Burkhardt, S., and Sültemeyer, D.: Carbon acquisition of bloom-forming marine phytoplankton, Limnol. Oceanogr., 48, 55-67, 2003.

Roy, R. N., Roy, L. N., Vogel, K. M., Porter-Moore, C., Pearson, T., Good, C. E., Millero, F. J., and Campbell, D. M.: The dissociation constants of carbonic acid in seawater at salinities 5 to 45 and temperatures 0 to $45^{\circ} \mathrm{C}$, Mar. Chem., 44, 249-267, 1993.

Shelly, K., Heraud, P., and Beardall, J.: Nitrogen limitation in Dunaliella tertiolecta Butcher (Chlorophyceae) leads to increased susceptibility to damage by ultraviolet-B radiation but also increased repair capacity, J. Phycol., 38, 713-720, 2002.
Shi, D., Kranz, S. A., Kim, J. M., and Morel, F. M. M.: Ocean acidification slows nitrogen fixation and growth in the dominant diazotroph Trichodesmium under low-iron conditions, P. Natl. Acad. Sci., 109, 3094-3100, 2012.

Sobrino, C., Ward, M. L., and Neale, P. J.: Acclimation to elevated carbon dioxide and ultraviolet radiation in the diatom Thalassiosira pseudonana: Effects on growth, photosynthesis, and spectral sensitivity of photoinhibition, Limnol. Oceanogr., 53, 494-505, 2008.

Sobrino, C., Segovia, M., Neale, P. J., Mercado, J. M., GarcíaGómez, C., Kulk, G., Lorenzo, M. R., Camarena, T., van de Poll, W. H., Spilling, K., and Ruan, Z.: Effect of $\mathrm{CO}_{2}$, nutrients and light on coastal plankton. IV. Physiological responses, Aquat. Biol., 22, 77-93, 2014.

Tortell, P. D.: Evolutionary and ecological perspectives on carbon acquisition in phytoplankton, Limnol. Oceanogr., 45, 744-750, 2000.

Wang, M. and Wang, G.: Oxidative damage effects in the copepod Tigriopus japonicus Mori experimentally exposed to nickel, Ecotoxicology, 19, 273-284, 2010.

$\mathrm{Wu}, \mathrm{H}$. and Gao, K.: Responses of a marine red tide alga Skeletonema costatum (Bacillariophyceae) to long-term UV radiation exposures, J. Photoch. Photobio. B, 94, 82-86, 2009.

Wu, H., Gao, K., Villafañe, V. E., Watanabe, T., and Helbling, E. W.: Effects of solar UV radiation on morphology and photosynthesis of filamentous cyanobacterium Arthrospira platensis, Appl. Environ. Microb., 71, 5004-5013, 2005.

Wu, Y., Gao, K., and Riebesell, U.: $\mathrm{CO}_{2}$-induced seawater acidification affects physiological performance of the marine diatom Phaeodactylum tricornutum, Biogeosciences, 7, 29152923, doi:10.5194/bg-7-2915-2010, 2010.

$\mathrm{Xu}, \mathrm{K}$. and Gao, K.: Reduced calcification decreases photoprotective capability in the coccolithophorid Emiliania huxleyi, Plant Cell Physiol., 53, 1267-1274, 2012.

Zacher, K., Hanelt, D., Wiencke, C., and Wulff, A.: Grazing and UV radiation effects on an Antarctic intertidal microalgal assemblage: a long-term field study, Polar Biol., 30, 1203-1212, 2007.

Zheng, Y. and Gao, K.: Impacts of solar UV radiation on the photosynthesis, growth, and UV-absorbing compounds in Gracilaria Lemaneiformis (Rhodophyta) grown at different nitrate concentrations, J. Phycol., 45, 314-323, 2009. 